\title{
Человек Достоевского - человек веры и любви
}

\section{Гюльнара Анвер Алиева 1}

Resumo: O artigo trata da concepção de homem na obra de Dostoiévski, que dos anos 40 até os anos de 80 do século XIX passou por uma série de estágios de desenvolvimento - desde o romance Gente pobre até a epopeia filosófica Os Irmãos Karamazov. Dostoiévski elaborou a sua filosofia do homem com base na idéia e na prática da humildade espiritual e do amor cristão. De acordo com o grande escritor, a verdade encontra-se no/é o caminho do amor pelo povo, da humildade diante do mal e do perdão de todos os culpados. O homem de Dostoiévski é, antes de tudo, um homem de fé e amor, um homem moral e espiritualmente perfeito.

Palavras-chave: Dostoiévski, concepção de homem, crença em Deus.

Abstract: The article deals with human conception in F. M. Dostoevsky's creativity. This conception passed through different stages of development from 40-s till 80-s of the XIX century, from the novel "Poor Folk" till philosophical "Karamazov brothers". Dostoevsky worked out his human philosophy, based on idea and practice of moral obeyment and Christian love. The writer considered the truth to be in the way of love towards human, obeyment before evil and forgiveness. A human being is a man of belief and love, a morally and spiritually accomplished one.

Keywords: F. Dostoyevsky, human conception, trust in God.

Аннотация: В статье рассматривается концепция человека в творчестве Достоевского, которая прошла ряд этапов развития, начиная с 40-х, кончая

1 Диссертант Бакинского славянского университета. Баку, Азербайджан. E-mail: gulya55569@mail.ru 
началом 80-х годов XIX века - от романа «Бедные люди» к философской эпопее «Братья Карамазовы». Достоевский разработал свою философию человека, которая опиралась на идею и практику духовного смирения и христианской любви. По мнению великого писателя, истина находится на пути любви к людям, смирения перед злом и прощения всех виноватых. Человек Достоевского - это прежде всего человек веры и любви, человек нравственно и духовно совершенный.

Ключевые слова: Достоевский, концепция человека, вера в Бога.

Весь свой талант Ф.М. Достоевский посвятил раскрытию тайны человека, все его внимание было устремлено на человека с его душевным складом, с образом его жизни, его чувств и мыслей. Он разгадывал человека как тайну и, разгадывая его всю жизнь, не считал свое время потерянным. В глубине человеческой природы Достоевский раскрывает Бога и дьявола и бесконечные миры, но всегда раскрывает из какого-то исступленного интереса к человеку. Существование Бога и предназначение человека для Достоевского - не просто «точки зрения», а вопросы жизни и смерти.

Концепция человека у Достоевского, её художественная реализация прошли ряд этапов развития, начиная с 40-х, кончая началом 80-х годов XIX века - от романа «Бедные люди» к философской эпопее «Братья Карамазовы».У Достоевского человек изображается через раскрытие его духовного мира. При этом с потрясающей гениальностью раскрывается судьба человека, пережившего глубокие духовные кризисы. Великий писатель с непревзойденной силой раскрывает в своих произведениях светлые и темные стороны человеческой души, такие демонические стихии в человеке, как грех, преступление и эгоизм, а также движения правды и добра в человеческой душе, состояние сатанинского и ангельского начал в человеке и т д. Чтобы вести разговор о человеке в целом, открыть новые, неисследованные глубины человеческой души, показать человека в его устремлениях и тайных движениях души, надо было иметь соответствующее образное мышление, которым обладал Достоевский, произведения которого можно назвать философскими трактатами. 
По словам Н. А.Бердяева, «Достоевский - величайший русский метафизик, вернее антрополог. Он сделал великие открытия о человеке, и от него начинается новая эра во внутренней истории человека. После него человек уже не тот, что до него. Эта новая антропология учит о человеке, как о существе противоречивом и трагическом, в высшей степени неблагополучном, не только страдающем, но и любящем страдания». [2, 154].

Трагизм собственной судьбы помог Достоевскому ощутить такие глубины трагического в мире и в человеке, которых многие не видят или вообще не хотят видеть. Трудная жизнь в бедности, каждодневный литературный труд на износ, тяжелое нервное состояние, вынесенное им в молодости во время смертного приговора, который был отменен в последнюю минуту перед расстрелом и заменен каторгой, нелегкие годы жизни, проведенные в Сибири, затем разочарование в былых идеалах, сомнения в существовании Бога и жажда верить в Бога - таким был духовный путь великого писателя.

Достоевский в своих произведениях указывает на скрытую в человеке склонность к агрессии, на утрату современным человеком смысла жизни, на одиночество и трагизм человеческого существования, порождающие сильнейшее внутреннее потрясение. В его произведениях 40-х годов изображены были низкие слои общества, бедные, маленькие люди. Как гуманист, в то же время как реалист Достоевский, раскрывая сложный душевный мир человека, проникая в глубину психологии униженного человека и показывая его боль, страдания, передавал правду жизни и обосновывал поступки и поведения своих персонажей их образом жизни и социальной средой. Если в 60-е годы в характерах и деяниях героев-идеологов Достоевского противостояли две силы - идея и нравственность,- то в 70-е годы основные герои писателя мучаются над разрешением противоборства в их душах двух сильных мотивов: веры в Бога и веры в человека, то есть религии и философии.Ф.М.Достоевский разработал свою философию человека, которая опиралась на идею и практику духовного смирения и христианской любви.

Достоевский начал свою литературную деятельность в 40-ые годы X1X века, когда в русской литературе главенствовала натуральная школа Гоголя, которая ставила во главу угла принцип социальной детерминированности человеческого характера. Реалистическая литература того времени изображала человека как явление прежде всего социальное, как продукт социальной среды и 
бюрократического общества. Таким изображались так называемые «маленькие люди» Гоголя, ярким представителем которых был герой «Шинели» Акакий Акакиевич. Он изображен в чисто социальном плане, изображен не как человек со своими нравственными чувствами и духовными потребностям, а как чиновник без всяких моральных качеств. Достоевский по-новому подошел к человеку и изобразил его прежде всего с психологической точки зрения, со всеми его чувствами и переживаниями. При этом писатель не отрицал влияния социальной среды на характер и судьбу человека. Но наряду с этим, Достоевский подчеркивал наличие в человеке твердого, неистребимого никакими социальными влияниями и бедностью нравственного начала. Это придало человеку Достоевского двойственное содержание: с одной стороны, человек - это социальный феномен, зависящий от своего материального положения и места, занимаемого в бюрократической системе, а с другой стороны, он духовно-нравственный феномен, зависящий от своей человеческой природы. «В человеке всегда есть чтото, что только сам он может открыть в свободном акте самосознания и слова, что не поддается овнешняющему заочному определению» $[1,68]$.

Человек Достоевского в отличие от человека Гоголя, не вмещается в социальное определение. Поэтому к человеку Достоевского нужно еще и психологическое, нравственное отношение. В этом вопросе, то есть в вопросе соотношения социального и нравственного начал в характере «маленького человека» у Достоевского, вполне диалектичным можно считать мнениеЕ.П.Порошенкова, который писал: «Социальное зло отравляет чистую душу маленького человека, заражает его поползновениями на хитрость, склонностью к подлым поступкам. Внешний конфликт становится внутренним: силы зла проникли внутрь души человека, полем боя стала душа человека» $[6,144]$.

Достоевский в 40-ые годы, находясь под влиянием ученых-теоретиков натуральной школы, рассматривал проблему человека и гуманизма с психологической точки зрения, противостоящей социальной точке зрения, т.е. осмысления человека как категории социальной. Тут Достоевский еще не создал своей теории и философии гуманизма. Автор «Бедных людей» гуманизм воспринимал, описывал просто как доброту, противостоящую социальной бедности и униженности. Макар Девушкин просто добрый человек, добрый от природы, который бескорыстно любит Варвару Доброселову. И его доброта проходит испытание бедностью. В данном случае гуманизм - это просто 
человеколюбие, сострадательность, честность и порядочность. Благодаря природной доброте души, Макар Девушкин бескорыстно любит Варвару Доброселову и живет для нее. Смысл своей жизни он понимает, как любовь к кому-то и как жизнь ради кого-то. Это и есть его счастье - жить для кого-то. Наоборот, трагедия его начинается с того, когда он по своему социальному положению, то есть по своей бедности не может помогать любимому человеку.

В 40-ые годы в произведениях Достоевского противостоят две силы: доброта и бедность, то есть человеческое и социальное начала и, как правило, второе берет верх, но первое, т.е. гуманизм, не исчезает, не истребляется окончательно и не выветривается из души человека, как это было у гоголевского Акакия Акакиевича («Шинель»). В этот период Достоевский изображал человека в пересечении двух сил: гуманизма человеческой природы и деспотизма социальной среды. В этой борьбе, как правило, второе начало, то есть социальное начало, брало верх над нравственным началом, что предопределяло трагедию маленьких людей Достоевского. Характерная особенность изображения человека в творчестве Достоевского в этот период заключается в том, что в таких произведениях, как «Бедные люди», «Двойник» и др. человек изображается одновременно и как социальное, и как психологическое явление. Если Гоголь изображал «маленького человека» (Акакий Акакиевич из «Шинели») как чисто социальный феномен, просто как чиновника, за душою которого нет ничего нравственно - духовного, душа которого мертва и закрыта для любви и добра, то Достоевский показал своего Макара Девушкина, с одной стороны, как бедного и маленького чиновника, с другой стороны, как доброго и любящего человека. Это была великая вера в человека, вера в неистребимость человека в человеке. Тем самым молодой Достоевский показал себя как истинного гуманиста.

В романе «Бедные люди» и повести «Двойник», бедный человек из низов оказывается под сильным влиянием социальной и духовной сил - бедности положения и доброты души. Но в каждом из этих случаев в душе героя доминирует одна из указанных сил. В душе Макара Девушкина («Бедные люди») господствует чувство гуманизма.Он любит Варвару Доброселову и смысл своей существования видит в жизни во имя этой несчастной и одинокой девушки. Однако его гуманистические стремления и желания сталкиваются с социальным его положением, и бедность не дает Девушкину реализовать свои гуманистические стремления. 
В душе Якова Голядкина («Двойник») господствует социальная страсть тщеславное чувство утвердить себя в обществе и найти в ней достойное себе положение. Однако эта страсть сталкивается с тем гуманистическим началом, с тем нравственным чувством, которые изначально пребывают в его человеческой натуре и которые необходимо отдать в жертву во имя социального успеха и преуспеяния. Если бедность мешает Девушкину реализовать свои гуманистические желания, то нравственное чувство мешает Голядкину осуществить свои социальные планы. «Бедные люди» построены на чувстве любви и гуманизме, как исконных, природных качеств человека. Макар Девушкин любит Варвару Доброселовуне во имя каких-то практических целей, не для того, чтобы жениться на ней и построить себе семейный очаг. Девушкин любит ее бескорыстной отцовской любовью. Его «выгода» в данном случае заключалась в том, что он, живя для другого человека, чувствует себя счастливым, видит в этой жизни для другого смысл своего бытия. Девушкин готов отказать себе во всем, в самом необходимом только для того, чтобы чем-то облегчить жизнь Варвары, чем-то услужить ей. Это - любовь взаимная, и Варвара по-достоинству оценивает бескорыстное пожертвование Макара Девушкина. Единственная опора в жизни этих двух бедных и одиноких людей являются их взаимная любовь и забота друг о друге. Нравственная удовлетворенность любовью дает им забвение своей бедности и бытовых трудностей. Но как бы устойчива ни была духовная связь двух любящих, им невозможно бывает избежать трагического влияния на их судьбу бедности и незащищенности. Когда Макар Девушкин почувствовал свою беспомощность перед офицером, оскорбившим Варвару, то он пал духом, перестал уважать себя как человека и начал пить и тем самым признал свое поражение перед обществом. В это время появился Быков, который когда-то погубил честь молодой Варвары, и предложил ей выйти за него замуж. Хотя она его не любила и ни на какую счастливую жизнь с ним не надеялась, все равно согласилась стать его женой. Это был шаг отчаяния, что-то наподобие самоубийства. Пошла она на этот шаг, чтобы спасти прежде всего Макара Девушкина и избавить его от страданий и бессильного желания помочь ей. Таким образом, доброта и любовь бедных людей терпят поражение, они становятся жертвой бедности и незащищенности. Но главная идея романа это высокогуманистическая идея о том, что человек, в каких бы тяжелых условиях он не жил, никогда не теряет свою человечность, гуманизм души и не превращается в «мертвую душу», о которой писал Гоголь. Идея романа 
Достоевского высоко гуманная идея. Она заключается в том, что человеческое начало в человеке вечно живо и ни при каких обстоятельствах его нельзя уничтожить. А это уже есть победа гуманизма над социальной необходимостью, это есть фундаментальная и вечная жизненность гуманизма. Тем самым Достоевский поднял человека на неимоверную высоту и утвердил оптимистическую идею о вечности любви и гуманизма как извечного содержания человеческой души.

В творчестве писателя 60-х годов появляется новый тип человека, который получил название героя-идеолога.Это - Раскольников («Преступление и наказание»), Мышкин («Идиот»), и др., которые были одержимы какой-то идеей и были рабами этой идеи. Но наряду с идеей в душах этих героев вечно жило нравственное чувство, которое спасало их, не давало окончательно стать жертвой идеи. Например, Раскольников под влиянием своей идеи сильного человека совершает преступление, убивает старуху-процентщицу и ее сестру, но злодеем и окончательным Наполеоном, сеющим вокруг себя только смерть и зло, не становится. Его спасает то нравственное чувство, которое, по мнению Достоевского, скрыто и неистребимо живет в душе человека и в критические минуты спасает его от окончательного падения и духовной гибели.

В 70-80-е годы творчество Достоевского поднимается на новую высоту, когда у него появляется более глубокая философия человека, рассматриваемого и изображаемого также с двух позиций - философской и религиозной. Достоевский считает, что философское понимание сущности человека, при всей его логической последовательности и правдоподобности, не выражает истинной сущности человека. Человеческая жизнь и человеческое мироощущение, по Достоевскому, находят свое наиболее адекватное выражение именно в религии. При всей своей нелогичности и неправдоподобности религиозная концепция человека выражает подлинную сущность человека, ибо человеку, чтоб жить на земле, нужна не истина о неизбежной смерти, а вера в вечную жизнь и в бессмертие души человека.

В романах «Бесы», «Подросток», «Братья Карамазовы» Достоевский показывает трагедию героев, одержимых желанием философски, логически осмыслить человека и мир, показывает, как их логически и философски верные мысли и идеи приводят их к трагедии. 
Основная борьба и спор о человеке в романе «Братья Карамазовы» развертываются между двумя братьями: философом Иваном и монахом Алешей. В этом споре аргументы Ивана кажутся более чем убедительными, а у Алеши кроме конкретной веры, в сущности, нет никаких логических и философских аргументов. Но Алеша силен именно верой и беззаветной любовью к Богу. Тем самым он изначально и стихийно пребывает в истине и истина в конечном итоге оказываются на его стороне. А доводы Ивана при всей их убедительности и логической последовательности оказывается в конце концов неверными.

Казалось бы философия Ивана очень верна и вполне гуманна. Он от души заботится о страдающем человечестве, особенно не может мириться с незаслуженными, несправедливыми страданиями детей. Конечная гармония в мировом финале, которую Бог обещает людям, говорит Иван, не стоит слезинки незаслуженно замученного ребенка. Аргументы и принципы гуманизма Ивана убедительны с философской точки зрения и гуманны с этической точки зрения. Но он оказывается неправ в конечном итоге. О его неправоте говорит тот факт, что его якобы верная и гуманная философия приводит в конце концов к отцеубийству. Руководствуясь именно его философией о том, что если нет Бога, то человеку все дозволено, Смердяков, этот лакей и раб мыслей Ивана, убивает отца семейства Федора Карамазова. «Смердяков,- писал М.М.Бахтин,- уверенно и твердо овладевает волей Ивана, точнее, придает этой воле конкретные формы определенного волеизъявления. Внутренняя реплика Ивана через Смердякова превращается из желания в дело».[1,303] Проблема усугубляется тем, что Федор Павлович, как падшая личность, заслуживает ненависти своих родных сыновей. И отцеубийство, как тяжелейший нравственный грех, легло на плечи всех его сыновей. Это убийство сделало всех братьев виноватыми в крови отца. И всему этому причиной стали будто бы научно выверенные и логически верные аргументы Ивана Карамазова.

Для понимания философии Ивана и в целом концепции человека Достоевского большое значение имеют две книги из «Братьев Карамазовых»: «Рroи kontra» и «Русский инок». В первой главное место занимает поэма Ивана Карамазова о Великом Инквизиторе - кардинале римской церкви, по приказу которого «еретиков» сжигают на костре. Во второй речь идет о святом отце Зосиме, который живет в монастыре и к которому Алеша Карамазов поступает добровольно послушником. Великий Инквизитор и отец Зосим - это защитники 
двух верований: западного католицизма и восточного православия. Католическая церковь и католическая вера, по мнению Достоевского, строятся на идее власти церкви над человеком, а православная церковь опирается на чувство любви и сострадания к человеку, кем бы он ни был. Там главное -это наказание, а здесьлюбовь и прощение.

Тему спора с Алешей о гуманизме, о Боге и прощении Иван переносит в другую плоскость и другие пространственно-временные координаты и излагает её как конфликт Инквизитора с Иисусом Христом. Иван излагает свою философию и свой принцип гуманизма Алеше и говорит ему о Боге как о возвышенном идеале, которого не достоин человек, в душе которого живет этот идеал. Он признает величие Бога, его праведность, но не может принять Божьего мира таким, каков он есть и каким он создан Богом. Своим человеческим умом и человеческим гуманизмом Иван не может объяснить приемлемость всех тех преступлений, которые совершаются против невинных людей и прежде всего детей, и тех страданий, которые выпали на долю этих несчастных созданий. Отвергая законы Божеского мира, Иван хочет установить свои, человеческие, законы и свое, человеческое, понимание справедливости и гуманизма. То есть вся воля и вся свобода предоставляется человеку как вершителю судеб мира. Поэтому он заявляет, что человеку все дозволено, он свободен в своем желании. Зная, что Дмитрий готов убить Федора Павловича, Иван не мешает ему, даже уезжает из города. «Один гад съедает другую гадину, обоим туда и дорога», - говорит он, и не только говорит, но и считает это законом жизни.

В ту же ночь Федор Павлович был убит, но не старшим сыном Дмитрием, а побочным сыном Смердяковым, который является реальным двойником и выражением дурной половины души Ивана. А другим его двойником и фантастической половиной его души был Черт. Черт скрывается в самой философии Ивана и обнаруживается в лице отцеубийцы Смердякова. Bсе начинается с философии Ивана, кончается зловещей практикой Смердякова. А Черт как бы является нравственно-этическим выражением философии Ивана, которая на практике породила преступление, а в нравственно-духовном мире Ивана- Черта.

Антиподом Ивана является его младший брат Алеша Карамазов, которого он хочет обратить в свою веру, то есть заставить поверить в свою философию. Но Алеша остается непреклонным в своей вере, хотя временами Ивану удается 
посеять в его душе семена сомнения. «Алеша Карамазов - новый тип человека в творчестве Достоевского. Он сочетает в себе идеализм с реализмом, мистику с реальной жизнью, веру в Бога с верой в человека, мирскую деятельность с деятельностью духовной». [4,386]

Иван и Алеша стоят на противоположных позициях в понимании сущности человека. Иван понимает его как разумное, логически и философски мыслящее существо, а Алеша - как верующее в Бога и нравственно-духовное явление. Они смотрят на человека с разных позиций. Сначала кажется, что Иван прав в своих логически последовательных аргументах, а доводы Алеши слишком отвлеченны и мифологичны. Но потом реальная жизнь и практика доказывают, что лучше и вернее знал Алеша, что душа человека необъяснима через научные выкладки Ивана. То что кажется мифологией, оказывается истинным адекватом жизни.

Антитеза философии и веры, логики и духа, Ивана и Алеши повторяется на высочайшем уровне в антитезе Великого Инквизитора и Иисуса Христа из поэмы Ивана Карамазова. Там на позиции Ивана находится Инквизитор, а на позиции Алеши Иисус. Инквизитор апеллирует к реальному человеку, к его порокам и слабостям. Он доказывает Иисусу, что человек - существо слабое, лживое и ему нужнее земной хлеб, нежели святая вера. Поэтому людей надо накормить, дать им хлеба и взять взамен их волю, подчинить их своей воле. Им нужно добровольно подчиниться сильной воле избранных, каким себя считает Инквизитор. А Иисус, которого Инквизитор посадил в тюрьму и грозится сжечь его на костре, покорно слушает кардинала и ничего не говорит ему, не возражает, не спорит, ибо понимает, кардинал знает о нем все и отвергает его веру. «У Ивана и Инквизитора нет любви к человеку,- пишет М.К.Коджаев,- есть своя теория справедливости. Они считают гуманным и справедливым отнять у человека свободу и взамен дать им хлеб насущный».[4,380]

Кардинал фактически находится на стороне дьявола, который искушал Христа в пустыне, наталкивая его на совершение чуда: преврати камни в хлеба, и люди поверят тебе и пойдут за тобой. Но Иисус отказывается от предложения дьявола, ибо не хочет покорить волю людей, а хочет, чтобы они поверили ему свободно, со спокойной и непокоренной совестью. Как Иван Карамазов, так и Великий Инквизитор - трагические личности. Они, с одной стороны, любят людей, думают об их судьбе, а с другой стороны, сами того не желая, лишают их главного спасения - свободной веры. Ведь они не знают, что «не единым хлебом жив 
человек», и что наевшись, люди спросят: «А дальше что?» Земной хлеб не может быть смыслом и целью человеческого бытия. Таков закон человеческой души, ему нужно нечто большее, неоспоримее, нежели хлеб земной.

Итак, Иван и кардинал думают о материальных потребностях человека, а Алеша и Иисус - о его духовных потребностях. Без последнего, то есть без духовного начала человек превратился бы в простого животного, у которого кроме материальных потребностей ничего нет. Достоевский хочет показать, что человек может быть удовлетворенным и счастливым только как нравственнодуховное явление, то есть в единении с Богом своим и в вере в него. Лишив его этой высшей сущности, можно превратить его в животное или в бессердечного убийцу. Человек сначала должен стать человеком, а потом уже думать о прочих своих земных назначениях и потребностях. Земное не должно закрывать собой небесное, а человеческое не должно подменять Божеское.

Вл. Соловьев в своей статье «Три речи в память Достоевского» писал: «А любил он прежде всего живую человеческую душу во всем и везде, и верил он, что мы все род Божий, верил в бесконечную силу человеческой души, торжествующую над всяким внешним насилием и над всяким внутренним падением. Приняв в свою душу всю жизненную злобу, всю тяготу и черноту жизни, преодолев все это бесконечной силой любви, Достоевский во всех своих творениях возвещал эту победу. Изведав божественную силу в душе, пробивающуюся через всякую человеческую немощь, Достоевский приходит к познанию Бога и Богочеловека. Действительность Бога и Христа открылась ему во внутренней силе любви и всепрощения, и эту же всепрощающую благодатную силу проповедовал он как основание и для внешнего осуществления на земле того царства правды, которого он жаждал и к которому стремился всю свою жизнь»[5,290]. Читая эти строки, приходится согласиться с философом в том, что для Достоевского главное - это не внешнее, социальное, материальное и т.д. положение человека в мире, а душа человека безотносительно к материальному, но относительно к Богу. Главное это, когда человек не теряет связи своей души с Богом, когда у него нет противоречия и конфликта с Богом, и он не виноват перед Ним.

Достоевский, в отличие от Шекспира и от своего современника Л. Толстого, пытается максимум огородить душу человека от реального мира и реальных действий, направленных на изменение условий жизни или на восстановление каких-то нарушенных порядков справедливости. Человек Достоевского 
исключительно занят своей душой и связью её с Богом. И деятельность человека, его созидательная миссия, по Достоевскому, также должны реализоваться в сфере души, самосозидания, в сфере борьбы с самим собой, а не с миром. Именно это имел в виду Соловьев, говоря о победе героя Достоевского «над внешним насилием и над всяким внутренним падением». Сфера духа, души человека, а не сфера реального бытия и быта были главными объектами художественного изображения Достоевского. Поэтому его любимые герои (Соня Мармеладова, князь Мышкин, Алеша Карамазов) среди грязи, несчастья, ужасов сохраняют свою душевную чистоту и красоту.

Достоевский как писатель, философ и психолог, заглянув в глубину человеческой души в ее исключительном состоянии, художественно исследовал мотивы, порождающие преступления. Большинство героев Достоевского с жаждой свободы, отклонившись от норм нравственности, идут против законов жизни и при этом, присвоив себе право на злодеяние и преступление, протестуют против аморальных жизненных устоев, бунтуют и защищают теорию «все дозволенности». Основываясь на эту теорию, Иван Карамазов оправдывает совершенное убийство, а Раскольников делит людей теоретически на «тварей дрожащих» и «на право имеющих». Эти протесты в дальнейшем порождают новые преступления, вслед за ними еще больше страданий. В своих произведениях Достоевский исследует проблемы соотношения своеволия и внутренней свободы человека, наказания и страдания, любви и ненависти, изучает самые сокровенные глубины человеческого духа. «Если гуманизм учил о человеке, как о трехмерном существе, - писал Бердяев, - то для Достоевского человек уже четырехмерное существо. И в этом новом измерении открываются иррациональные начала, которые опрокидывают истины гуманизма. В человеке открываются новые миры. И меняется вся перспектива».[3.c.54]

Таким образом, творчество Достоевского составило новый этап в истории эволюции проблемы гуманизма и в разрешении проблемы человека. Во-первых, писатель дал новое объяснение сущности человеческого характера и его детерминантов. Писатель в отличие от реалистов натуралистического толка не сводил характер и судьбу человека исключительно к влиянию социальной среды. Наряду со средой важным фактором, определяющим психологию и судьбу человека, Достоевский считал натуру и душу человека, которые не сводятся к результатам социального влияния. Это дало писателю возможность объявить 
человека существом относительно свободным и стабильным в сохранении своих нравственных качеств в неблагоприятных для него социальных условиях.Вовторых, проблема человека в творчестве Достоевского проходит определенный путь эволюции от «Бедных людей» к «Братьям Карамазовым». И в этой эволюции выделяется три основных этапа: раннее творчество Достоевского, когда объектом его художественного изображения были так называемые «маленькие люди», творчество писателя 60-х годов, когда главными героями его романов стали герои-идеологи и, наконец, творчество 70-х годов, когда писатель пытался раскрыть религиозную и философскую суть человека.

Таким образом, человек Достоевского - это прежде всего человек веры и любви, человек нравственно и духовно совершенный, через совершенство которого проходит путь к совершенству мира и общества.

\section{Литература.}

1. Бахтин М.М. Проблема поэтики Достоевского.- М.:Сов.Россия.1979.- 320с.

2. Бердяев Н.А. Самопознание// Сочинения. - М. ЭКСМО-Пресс 1999 , с. 177 .

3. Бердяев Н.А. Миросозерцание Достоевского. Прага, Издательство YМСАPRESS, 1923,c.84.

4. Коджаев М.К. Характеры и идеи Достоевского.-Баку, Мутарджим,2007.- 464c.

5. В.С. Соловьев. Сочинения в двух томах. Т.2, М., Мысль, 1988, с 60.

6. Порошенков Е.П. Об одной идее повести Ф.М.Достоевского «Двойник»// Учен. зап. МГПИ им. Ленина, 1967.- №256,ч.1.- С.128-150. 